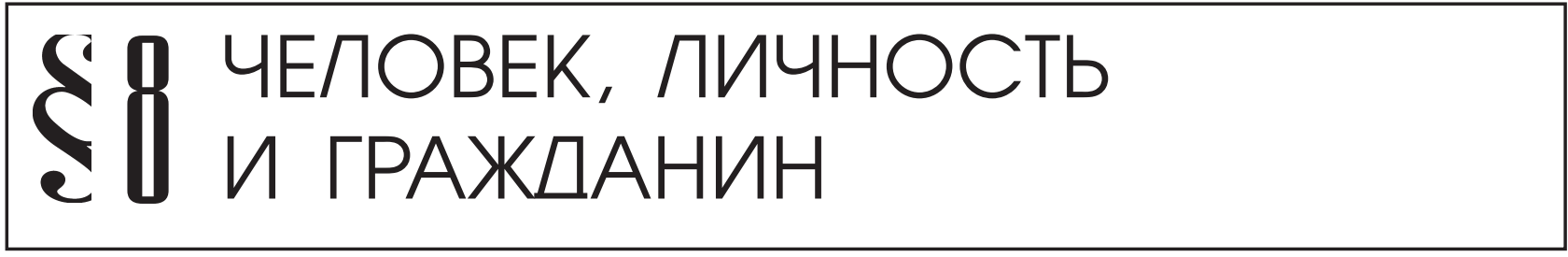

Деметрадзе M.P.

\title{
СОЦИАЛИЗАЦИЯ КАК СПОСОБ САМОАКТУАЛИЗАЦИИ ИНДИВИДА И РОСТА ЧЕЛОВЕЧЕСКОГО ФАКТОРА В РОССИИ И НА ПОСТСОВЕТСКОМ ПРОСТРАНСТВЕ
}

Аннотация: Работа посвящена вопросам преодоления традиционной консервативной культуры членов российского общества. В качестве способов преодоления рассматриваются механизмы социализации, самоактуализации, на которых основаны рост социальной мотивации индивида, овладение навыком артикулячии сочиальных запросов. Предлагается концепиия соииализации как стратегическая составляющая современной социокультурной политики. Анализируются современные ценности и обычаи, повышающие роль, статус человека, а так же принципы «конституционализации человеческого фактора в государстве».Ключевые слова. Сочиализачия, человеческий капитал, обыденная жизнь, самоактуализаиия, стандарт жизни, качество жизни, уровень жизни, жизненный мир, современные социальные стандарты.В рамках данной статьи теория иентральной зоны социокультурных иенностей в иелом и теория иентральной зоны традиционных ценностей как ее конкретизация для традиционного общества нами не рассматриваются несмотря на ключевое значение для рассматриваемой проблематики и разрабатываемой нами методологии социокультурных исследований. Не рассматриваются также модели сочиализации для других обществ постсоветского пространства. Отметим только, что, поскольку иентральная зона соииокультурных иенностей в каждом обществе имеет особенные черты, модели социализачии должны их учитывать.

Review: The article is devoted to overcoming the traditional conservative culture represented by the members of the Russian society. The author of the article lists particular methods of overcoming it such as mechanisms of socialization, self-actualization and growth of social motivation and acquiring a skill of articulation of social requests. The author describes the socialization conception as a strategic element of modern socio-cultural policy. The author also analyzes modern values and beliefs increasing the role and status of human being as well as the principles of 'constitutionalization' of human resources. The author underlines that the central zone of socio-cultural values has its own peculiarities in each society and therefore it is important to keep that in mind when implementing a particular model of socialization.

Ключевые слова: Социализация, сочиокультурный статус гражданина, человеческий капитал, обыденная жизнь, самоактуализация, стандарт жизни, качество жизни, уровень жизни, жизненный мир, современные сочиальные стандарты

Keywords: Socialization, socio-cultural status of a citizen, human resources, everyday life, self-actualization, living standards, quality of life, life world, modern social standards.

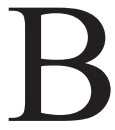

ажнейшей задачей современного российского общества, как и обществ всего постсоветского пространства, является преодоление традиционализма, препятствующего развитию общества по пути к демократии. Как показывает опыт последних десятилетий, преодоление традиционализма встречает сопротив- ление во всех сферах жизни общества, включая социально-гуманитарные науки. Этому явлению есть теоретическое объяснение, которое мы получили при разработке теории центральной зоны социокультурных ценностей. Согласно нашим выводам, особенности центральной зоны традищионных социокультурных ценностей кон- 
ституируют социокультурное пространство на принципах незыблемости традиционных устоев, культурной самобытности, консервативного уклада и образа жизни и т.д., что порождает девиантные формы поведения индивидов - ритуализм, бегство от действительности и стигматизацию. Общество, характеризующееся такими чертами, воспроизводит традиционализм и преграждает каналы проникновения современных социокультурных ценностей в центральную зону культуры, что является главным фактором, препятствующим модернизации.

Возможно ли разорвать цепочку воспроизводства традиционализма? Положительный ответ на этот вопрос дает концепция социализации.

Поскольку темой данной статьи является социализации именно русского общества, необходимо выделить специфические черты традиционализма, на преодоление которых должна быть направлена социализация ${ }^{1}$.

Здесь нас интересуют формы традиционализма, снижающие роль и статус русского человека в собственном государстве. Опуская анализ, позволивший нам получить определенные выводы, выделим прежде всего приспособленческую традиционную культуру русского человека, принявшую форму приспособленческой девиаци, опирающуюся на изоляиионизм, бегство от свободы, уступчивость при речении социильных вопросов и ориентация на зависимость от государства и правящей верхушки, нерешительность, беспомощность, обособленность, агрессивность и т.д. Все это вместе говорит о том, что русское общество в основном является носителем так называемой дефицитарной социальной мотивации (довольствоваться элементарными социальными условиями), дефицитарным само-

\footnotetext{
${ }^{1}$ В рамках данной статьи теория центральной зоны социокультурных ценностей в целом и теория центральной зоны традиционных ценностей как ее конкретизация для традиционного общества нами не рассматриваются несмотря на ключевое значение для рассматриваемой проблематики и разрабатываемой нами методологии социокультурных исследований. Не рассматриваются также модели социализации для других обществ постсоветского пространства. Отметим только, что, поскольку центральная зона социокультурных ценностей в каждом обществе имеет особенные черты, модели социализации должны их учитывать.
}

уважением и дефицитарной самоактуализацией.

Но, как сказал известный представитель когнитивизма в теории личности Джордж Келли, «человек не нуждается в том, чтобы быть рабом своего прошлого опыта, если только он сам не соглашается с таким истолкованием собственной персоны» ${ }^{2}$.

Действительно, важно не только раскрыть, как люди интерпретируют свой жизненный опыт и свое положение в обществе и т.д., но и предложить научно разработанные концепции трансформации традиционного человека в современного гражданина, умеющего поддерживать современный образ и стиль жизни, - концепции замещения отживших свой век способов интерпретации современными. Например, путем приобщения к таким социокультурным традициям как «социиальный контакт», «социиальные отношения», "соичиальная зависимость», «социиальный контроль», "социиальная организацчия», "социальная связь», "социальная общчность», «социальная мобильность», "сочииальное движение», «социальное развитие», которые требуют от индивида понимания необходимости изменения отношения к жизненным ситуациям.

В том, что это необходимо, сомнения нет. Девиации и устойчивость консервативных ценностей ядра культуры несовместимы не только с современными социокультурными традициями, но и рационально-конструктивными нормами вообще, а носители дефицитарных социальных потребностей и мифодискриминантного девиантного сознания неспособны формировать общество среднего класса, социальное государство, партнерские отношения между обществом и государством. Они не могут и сформулировать соответствующие запросы, а значит, не могут и трансформировать ядро центральной зоны культуры - этому нужно обучаться специально.

Поскольку в России никогда не было благоприятных условий для развития гражданского общества, специальное обучение новым поведенческим моделям следует разрабатывать в рамках социализации современных социокультурных ценностей и традиций. Разумеется, не копируя - не американизируя, не офранцуживая, не онемечивая русский

\footnotetext{
${ }^{2}$ Цит. по: Хьелл Л., Зиглер Д. Теории личности. 3-е изд. СПб.: Питер, 2006. С. 438.
} 


\section{Политика и общество 11 (107) • 2013}

(как и любой другой) народ, а заимствуя современные социокультурные ценности.

На наш взгляд, необходима разработка моделей действия и взаимодействия индивидов, рационализации и самоорганизации жизни общества на основе категорий «образ жизни», «уклад жизни», «уровень жизни», «качество жизни», «стиль жизни», «стандарт жизни», «человеческий фактор» $u$ m.д. Социализацию мы рассматриваем в данном случае как коммуникативный феномен создания условий трансформации традиционного общества через освоение паттернов современной социокультурной жизни.

Согласно объективистскому подходу Дюркгейма, каждое новое поколение - это почти tabula rasa (чистая доска), на которой обществу предстоит писать заново. По его мнению, основная функция социализации - приобщение индивидов к идее «коллективного сознания» или установление целостности общества. Отсюда цель воспитания - формирование социального существа, заключающееся в последовательной социализации нового поколения ${ }^{3}$.

Тард выдвинул идею подражания - интернализации норм через социальное взаимодействие в модели «учитель - ученик» ${ }^{4}$. Гиддингс предложил оригинальную идею социализации - социального принуждения, поскольку в обществе присутствуют две силы приобщения к социализации - «волевой процесс» и «искусственный отбор», необходимые для сознательного выбора пути развития и самореализации 5 . Парсонс рассматривал социализацию как фактор поддержания социального равновесия и средство социального контроля 6 . Основатель «критической теории социализации» Хабермас представил процесс социализации в контексте социальной организации общества, где человек выполняет определенную роль на основе социальных норм и ценностей и при этом критически относится к своему жизненному миру.

Ценным для нашей темы представляется подход Смелзера к социализации - как к процессу накопления опыта и социальных установок, соот-

\footnotetext{
${ }^{3}$ См.: Дюркгейм Э. Социология образования. М., 1996.

${ }^{4}$ См.: Тард Г. Законы подражания. СПб., 1989.

${ }^{5}$ См.: Giddings F.P. The theory of socialization. New York. 1892.

${ }^{6}$ См.: Parsonc T. The social system. Glencoe. 1951.
}

ветствующих социальным ролям и стандартам ${ }^{7}$. Известный российский ученый И.С. Кон, который еще в советские годы отстаивал идею первичности человека в государстве, выделяет две формы социализации: адаптацию - приспособление к новым условиям, ролевым функциям, социальным нормам; и интериоризацию - процесс установления социальных норм в обществе на основе принципа «человек - носитель современных иенностей», что обусловливает социальное поведение индивида ${ }^{8}$. Иными словами, социализация задает индивидам социальные черты, ценности, способы поведения, и ее результатом становится формирование социально ориентированных личностных моделей поведения.

Обобщая, можно сказать, что социализация необходима для внедрения социокультурных ценностей и мотивов поведения, образующих социокультурные традиции и обычаи, а также для смены паттернов поведения, трансформации традиционного человека в современного гражданина и замены содержания ядра центральной зоны культуры. Это означает, что социализации следует придать институциональный характер, а это со своей стороны выдвигает задачу ее рассмотрения как информационно-коммуникативного феномена, образующего связи как между индивидами, процессами и институтами и создающего нормы-образцы и нормы-правила поведения. Согласно такому подходу, за основу берется не традиционное понимание социализации в формах первичной (дошкольное и школьное образование) и вторичной (получение дальнейшего образования) социализации, а механизмы преодоления дефицитарных социальных запросов человека, его пассивности и запуска социокультурной трансформации человека. Результатом социализации должно стать признание человека высшей социокультурной ценностью государства. Это он созидает, творит, производит, создает общественное благо собственными либо коллективными усилиями, и только благодаря ему существует само государство.

В процессе социализации социокультурная методология выделяет три основные этапа: 1) подготовительный, 2) внедрения и 3) практической

${ }^{7}$ Смелзер Н. Социология. М., 1998. С. 95.

${ }^{8}$ См. Кон И. Психология ранней юности. М., 1989. 
реализации социокультурной политики, то есть политики, опирающейся на современные социокультурные ценности, традиции и обычаи.

Первый этап социализации. Подготовка к социокультурным переменам и социализации русского (постсоветского) общества

На этом этапе определяются специфические черты консервативного традиционализма русского человека и многонационального российского общества (а в других обществах - другие черты традиционализма), причины возникновения, устойчивости и институциональности девиантных форм поведения (дезинтегративная, приспособленческая и т.д.), а также типы политической, социальной, экономической, правовой и культурной активности (традиционной либо современной), условия возникновения традиционализма, воспроизводства отношений по принципу «господство - подчинение» и т.д.

Закладка основ институционализации социокультурного поведения предполагает вместе с тем полное устранение архаических форм культуры, верований, коллективных представлений, консервативно-радикальных ценностей, в частности, о незыблемости существующего порядка и образа жизни, сверхъестественной «силе» русского человека, идеологии «Евразийства» и др.

Подготовительный этап политики социализации - это самый сложный процесс, именно здесь сопоставляются традиционные и современные ценности и происходит перелом паттернов поведения, который может вызвать кризис во взаимоотношениях между носителями современных и традиционных ценностей. На наш взгляд, научный подход к социализации должен опираться прежде всего на социальные теории и теории персонологов, в том числе теорию, предложенную Генри Мюрреем ${ }^{9}$, при этом цель науки выходит далеко за рамки традиционных: ее цель - помочь людям получать социальное удовлетворение от жизни, преодолевать жизненные затруднения, открывать в себе новые возможности, то есть достигать конструктивных личностных изменений.

Однако следует учитывать, что в условиях устойчивости ядра центральной зоны традици-

${ }^{9}$ См.: Murray H. Explorations in personality. New York: Oxford University Press. 1938. онных ценностей индивиды, в первую очередь представители русского общества, могут неадекватно отреагировать на внедрение современных ценностей. Как показывает практика, они проявляют подозрительность ко всему новому, поэтому начальный этап социализации, безусловно, может вызвать кризис и конфликт в обществе. В связи с этим основным фактором подготовительного этапа социализации следует считать процесс адаптации, в рамках которого осуществляется запуск механизмов преодоления традиционализма - механизмов внедрения социокультурных принципов и усвоения навыка приобретения социокультурной компетентности. Следует иметь в виду, что кризис русского общества выражается в социальной беспомощности индивидов, которая должна быть заменена осознанием значения социальной жизни и вовлеченностью в нее. Это означает, что социализация должна приобщать к социокультурным переменам на принципах «я - то, что могу»и «Я - то чему научился» как самых надежных ориентирах преодоления комплексов неполноценности и замещения девиации аккультурацией, интериоризацฺией и ресоциализацุией.

Конечной целью социализации является формирование социально-активной и социально-ориентированной личности, наделенной социальными интересами, с четким представлением иерархии социальных потребностей, реализуемых путем самоактуализации и самореализации. Так, социокультурный контекст «Я» наделяет ответственностью индивида, причем социальные интересы индивида являются барометром его позиции, компетентности и зрелости. Важнейшая задача всего общества - поднять значение человеческого потенциала в государстве и обществе, раскрыть творческий потенциал личности, развитию которого нет предела, ибо развитие длится всю жизнь ${ }^{10}$. Человек - это существо, «берущее от жизни» благо не просто так, не прикладывая усилий, а умеющее творить, производить, формировать социально значимый капитал страны, обеспечивать переход общества на более высокий уровень развития. Это требует отношения к

${ }^{10}$ См.: Erikson E. Life history and the historical moment. New York. 1973. 


\section{Политика и общество 11 (107) • 2013}

человеку как к творцу основного капитала страны (сегодня в нашей стране таким капиталом являются исключительно природные ресурсы; в трансформированном обществе они должны использоваться и перераспределяться в интересах общества) с образованием и осознанием зависимости государства от человеческого фактора.

Под институционализацией понимаются социально-мотивационные действия людей, направленные на создание личного и общественного блага, обеспечивающие формирование прежде всего гражданина и общества с преобладающей ролью среднего класса. Важно отметить, что мы не рассматриваем социализацию как процесс создания социальных условий со стороны исключительно государства, поскольку это чревато воспроизводством социальной пассивности индивидов (ярким доказательством такой опасности являются провалы в политике построения «государства всеобщего благосостояния» в США и некоторых странах Запада). Для нас принципиальным является самоактуализация человека, его способностей, появление иерархии социальных запросов, стремления удовлетворять их собственными усилиями и умения выдвигать перед государством требования создать соответствующие условия для развития общества. И в этом суть социокультурной природы (а не просто социальной) человека как особого капитала, от развития которого будет зависеть будущее государства. Это означает, что самоактуализация в нашем понимании - это способ проявления человеком активности, артикуляции и агрегации социальных интересов, самореализации, функциональной автономии, зрелости, целеустремленности, ориентированности на будущее, социальных основ мышления и т.д. таким образом, самоактуализация поможет преодолеть такие черты традиционализма, как социальная неполноценность, приспособленчество, ухищренчество, патернализм, фанатизм и т.д.

Важность подготовительного этапа социализации состоит не только в определении проблем традиционализма и возможностей их преодоления, но и в том, что социализация предполагает научно обоснованную разработку конституционализации человеческого фактора - процесса наделения индивида определенным статусом, правами и обязанностями.
Для этого человеку не нужно быть Аристотелем или, как сказал видный персонолог Гордон Олпорт, сформулировать интеллектуальную теорию смысла жизни, а нужно знать систему социальных ценностей, которые служат объединяющей основой его жизни ${ }^{11}$.

Такая конституция ориентирует человека на социальные мотивы моделирования деятельности через социальные коды, обусловливающие целеориентированное изменение человека, которое, как считает другой видный персонолог XX века Альберт Бандура, обеспечивает власть человеку ${ }^{12}$.

Мы солидарны с позицией Джорджа Келли: «Эта система личностных конструктов дает человеку свободу решений и ограничение действий - свободу, потому что она позволяет ему иметь дело со знанием событий, а не с силами» ${ }^{13}$. Недостаток знания о социокультурной жизни, принципах социокультурной природы человека - это угроза для общества; общество должно знать, каким ему следует быть и чем оно может стать, если не будет обладать такими знаниями.

А) Обыденная жизнь человека как арена первичной социализации

Практическое осуществление социализации начинается в среде обыденной жизни, где уже в детстве закладываются мотивы неспециализированной формы деятельности человека. Она задает смысловую направленность, цель жизни и культуру поведения человека в обществе и государстве. Ее можно рассматривать как деятельность по формированию первичных условий жизни, межличностных контактов, обмена жизненным опытом и передачи опыта от поколения к поколению ${ }^{14}$.

Семья - один из основных институтов общества - играет важнейшую роль в системе неинституциональных форм деятельности человека

${ }^{11}$ См.: Allport G.W. Pattern and growth in personality. New York. 1961.

${ }^{12}$ См.: Bandura A. Social learning theory. Prentice-Hall. 1977.

${ }^{13}$ Kelly D. Man's construction of his alternatives. New York. 1958. P. 58.

${ }_{14}$ Орлова Э.А. Обыденная культура: организационные формы // Структура культуры и человек в современном обществе. М. 1987. С. 138. 
в обыденной жизни. Если рассматривать семью как «малую группу», можно сказать, что здесь происходит первичная социализация человека, которую П. Бергер, Б. Бергер и Р. Коллинз назвали «процессом перехода, благодаря которому индивид обучается быть членом общества, где происходит наложение социальных паттернов на поведение» ${ }^{15}$. В семье также происходит интернализация, формирование сознания, открытие себя и внешнего мира и т.д.

Выделение в качестве первоисточника социализации обыденной жизни человека и его семью не случайно, так как отсюда начинается связь индивидов с другими социальными институтами государством, системой образования, учреждениями культуры и т.п. Здесь же формируются статусно-ролевые функции, основанные на категориях «долг», «честь», «обязанности», «ответственность», «индивидуальность», «интерес», «мотивация», «стимул», «поощрение», «сострадание», «защитта», «соичальная безопасность», «сочиальное благополучие»и т.п.

В рамках обыденной жизни приобретаются естественные навыки, здесь же происходит их агрегация с выделением собственно социокультурных запросов, необходимых для полноценной жизни индивида. Именно на этой основе человек начинает поиск путей реализации своих возможностей, формирует контакты с окружающим миром. Уже здесь выстраивается и иерархия социальных потребностей, и поскольку она напрямую зависит от благополучия семьи, поэтому создание условий для благополучия семьи - прямая обязанность государства, если оно желает не на словах, а на деле считаться современным, то есть опираться на поддержку граждан, разделяющих современные социокультурные ценности.

Резюмируя, еще раз подчеркнем, что мы рассматриваем человека как социокультурное существо, имеющее соответствующие запросы, способное удовлетворять эти запросы собственными усилиями и благодаря навыкам, являющимся барометром его зрелости и культурной компетентности. В обыденной среде человека (в семье прежде всего) должны быть заложены условия конституционализации человеческого факто-

\footnotetext{
${ }^{15}$ Бергер П., Бергер Г., Коллинз Р. Личностно-ориентированная социология. М. 2004. С. 76.
}

ра как источника усиления роли человека в государстве, и в этом мы усматриваем первостепенную значимость социализации.

Б) Самоактуализация человека и его социальные запросы как основа конституционализации человеческого фактора

Использование понятия «обыденная жизнь» предоставляет возможность рассматривать человека как социокультурное существо, имеющее прежде всего естественные запросы, к числу которых относятся социальные потребности и интересы индивида. Знание их типологии и понимание иерархии позволяют определять соответствующие механизмы актуализации запросов и способы решения социальных проблем, а также определять институты, отвечающие за качество жизни и социальное благополучие граждан.

Социальные запросы человека (комплекс его социальных потребностей) не носят ультимативный характер, но являются основополагающей частью естественных запросов, лежащих в основе естественного права. Они сопровождают человека начиная с самого раннего детства до конца жизни.

С точки зрения концепции социализации, первичными запросами человека являются семья, жилище, домохозяйство, образование, достойное качество жизни и социального обеспечения, социальный иммунитет и социальная защищенность, социальное равновесие в обществе и социальная безопасность, возможности социальной адаптации и роста социального статуса и т.п. Создание условий для удовлетворения первичных запросов является первостепенной задачей государства.

Поскольку социальные запросы являются важными стимулами практической деятельности человека, умение их артикулировать необходимо не только для получения статистических данных (хотя и это необходимо для владения точной информацией о реальном положении дел в обществе), но и для определения мобилизациионного ресурса конкретных форм деятельности индивида и повышения стимулов к самоактуализациии индивидов, ведущих к росту политической культуры, то есть культуры участия в общественных процессах и влияния (партисипация) на принятие государственных решений.

В связи с этим для обеспечения институционализации процесса самоактуализации челове- 


\section{Политика и общество $11(107) \cdot 2013$}

ка основное внимание следует уделить категории адаптации. Один из основных механизмов проявления социальной природы человека, адаптация - это процесс, в ходе которого происходит зарождение и закрепление связей человека с повседневной реальностью, его контактов с предметами и пространственной средой, на основе которых индивидуальными и коллективными усилиями создаютя жизнеобеспечивающие и жизнеподерживающие условия, принимаюие социальный характер.

Способность индивида к адаптации есть показатель его стартовых позиций, возможностей в социуме, форм, качества и стиля обыденной жизни, деловых качеств, общественной активности и т.п. Все это усиливает роль и статус человека в государстве, и свой подлинный статус человек обретает тогда, когда он рассматривается как основной субъект и объект социокультурного пространства и социокультурных процессов, который наделен социальной, биологической и культурной природой, умением мыслить, производить и творить, способностью наполнять содержанием свой жизненный мир и создавать условия жизнедеятельности и жизнеобеспечения собственными или коллективными усилиями.

Но чтобы человеческий фактор доминировал в обществе, необходимы конкретные знания об адаптации, естественно возникшей среде жизнедеятельности человека, предпосылках и условиях формирования его жизненного мира.

Жизненный мир индивида отражает этапы жизненного пути человека, его склонности и ориентиры, показатели уровня, стиля и качества жизни, которые зависят от конкретных условий и умения индивида направлять свои способности на удовлетворение собственных запросов и потребностей, и создание такого содержания жизненного мира, к которому он стремится.

Адаптация и жизненный мир вводят (исходя из принципов самоактуализации человека и его трансформации в современного гражданина) функциональные императивы практической деятельности человека, посредством которых выделяются конкретные социальные запросы в жизненном мире и социокультурном пространстве индивида. В качестве таких конкретных запросов выступают материальные и нематериальные запросы. Материальные запросы - это товары и продукты широкого назначения, объекты социального характера для обеспечения материального и нематериального благосостояния и удовлетворения разносторонних потребностей.

Нематериальные запросы - это запросы, создаюие социально полезную среду жизнедеятельности индивидов и первичных групп и обеспечиваюие социальное равенство, социальное благополучие и социальную безопасность общества в целом.

В качестве основных субъектов создания материальных и нематериальных благ выступают как сам человек, так и общество и специализированные институты, действующие на основании иерархии социальных ценностей.

Чтобы оценить качество жизненного мира требуется знание качественных показателей материальных и нематериальных естественных и социально значимых запросов индивидов. Их измерение необходимо для сравнения с современными стандартами, изучения реально сложившихся условий жизни индивида.

Достойный уровень жизни также относится к системе социальных запросов граждан. Он отражает совокупность показателей, характеризующих обеспеченность населения необходимыми для жизни материальными и нематериальными благами и степень удовлетворенности этими благами.

Такие социальные потребности человека, как обеспечение высокого качества и стиля жизни, являются неотъемлемой составной частью содержания категории «достойный уровень жизни", они внедряют функциональные императивы для социальных, экономических, политических и правовых институтов. Эти категории четко соединяют общественные процессы с качественными показателями повседневной жизни.

Качество жизни - это качественные показатели жизненной среды человека: конкретных условий быта, труда, отдыха, жилищных условий, получения образования, охраны здоровья, продуктов питания, социальных институтов и социокультурного пространства в целом. Характер качества жизни определяет и особенности стиля жизни индивида и общества (традиционное - современное). 
Стремление к высоким качественным показателям уровня жизни как естественная потребность человека повышает его социальный статус в социокультурном пространстве и образует связь с запросом на качество «стиля жизни» $u$ «образа жизни».

«Стиль жизни» - это образцы поведения, в основе которых лежат ценности, стереотипы, установки, мотивы, склонности, определяющие стартовое и статусное социальное положение индивидов и групп. Достойные уровень, качество и стиль жизни как первоочередные естественные запросы человека играют ключевую роль в процессе адаптации человека в социокультурном пространстве, так как показывают не только каналы «входа» индивида в систему, роль человека в обществе и условия его жизнедеятельности, но и ту позицию, которую может занять индивид в социокультурном пространстве.

Благодаря этим показателям социализация определяет ролевую, статусную и стратификационную структуру общества, принадлежность индивида к той или иной страте (элита, высшие, средние, низшие слои или социальное «дно») по признаку занимаемых социальных позиций и статуса, характеризующихся сходством или различиями в образе, качестве и стиле жизни с учетом активности включения человека в жизненную среду и социокультурное пространство.

Иными словами, адаптация закладывает основы не только деятельности, но и взаимодействия человека с окружающей средой и внедряет принципы организации жизненных условий, упорядочивания первичных социальных потребностей человека и его социального взаимодействия со средой. Человек как социокультурное существо, наделенное социальной и культурной природой, создает свой «образ жизни» - среду, отражающую характер самоорганизации, социальной позиции и социальной практики человека с учетом его индивидуальных качеств, способностей и стремлений, определяющих качество и стиль жизни.

Рассмотренные социальные запросы человека - обеспечение безопасности, достойного уровня, качества, стиля и образа жизни, защиты от бедности и безработицы, удовлетворения материальных запросов - являются основополагающими стартовыми позициями человека в процессе адаптации в жизненной среде. Именно они со- ставляют основные «статьи» конституции современного человека, знание которых отвечает вызовам времени и востребовано необходимостью перехода от традиционализма к современности. Они создают запускающие механизмы социально-координирующих мотивационных ориентиров адаптации традиционного человека к современным процессам, формируют поле жизнедеятельности, каналы входа социокультурных ценностей в ядро центральной зоны социокультурных ценностей, образуют стимулы и реакции рационального характера. Приобщение к знанию современных социальных ценностей и соответствующих им запросов является первоочередной задачей социализации, подготавливающей основу для реализации ее второго этапа.

Исходя из того, что знание перечисленных ценностей (а мы рассмотрели далеко не все социокультурные запросы индивида) и умение выстраивать их иерархию создают стимулы к самоактуализации индивида и требуют специальной подготовки, целесообразно разработать и внедрить в учебный процесс новый предмет - «Конституционализация человеческого фактора и человеческого капитала в современном государстве». Преподавание этого предмета должно опираться на социальную, культурную, правовую, экономическую и политическую антропологию, позволяющие ставить в центр внимания человека и его запросы и возможности их удовлетворения.

Второй этап социализации. Внедрение социокультурных ценностей

На этом этапе происходит изменение позиции и активности граждан, и, соответственно, растет их влияние на политические процессы. Растет и значение таких категорий как «образ жизни», «уклад жизни», «уровень жизни», «качество жизни», «стиль жизни», «стандарт жизни» и т.п.: поскольку именно они становятся мерилом качественных характеристик политики, они все больше определяют ее цели. Все эти категории должны базироваться на таких понятиях, как «человек», «деятельность», «семья», «потребности», «человеческий потенциал» и т.д., которые не только выражают конечные результаты социальной политики, но и обусловливают связь самой политики с повседневной реальностью. 


\section{Политика и общество 11 (107) • 2013}

Теоретическое осмысление и внедрение в общественное сознание значения категории «уровень жизни» необходимо для оценки степени удовлетворения социальных запросов и потребностей индивидов в соответствии со стандартами, отраженными в Конвенции ООН по правам человека. Этот блок охватывает такие показатели, как доходы, заработная плата, льготы, выплаты из различных фондов, качество потребительских товаров, продуктов и услуг, уровень образования, здравоохранения, жилищные условия и т.д.

Распространение знания современных стандартов жизни крайне необходимо для постсоветских обществ, так как советский человек привык довольствоваться дефицитарными потребностями, нормы которых определяла правящая верхушка. Ведь привычка довольствоваться самыми элементарными жизненными условиями, навязываемая советским людям, не знавшим современные стандарты из-за «железного занавеса», во многом способствовала распространению практики незаконного «заработка», так как существующие стандарты имели мало общего с реальными социальными запросами человека. Показатели качества жизни позволяют определить качество и степень удовлетворения потребностей и запросов индивидов - от самых элементарных до самых сложных, соответствующих образу жизни современного человека. Стремление к повышению стандартов качества жизни ведет к изменению представлений о социальном укладе жизни, масштабной переориентации традиционных устоев и т.д. Можно констатировать, что широкое распространение и применение категорий «уклад жизни» и «качество жизни» во многом способствуют трансформации самооценки постсоветского человека и его отношения к своему месту в обществе, а именно: он будет позиционировать себя и относиться к себе прежде всего как социальное и культурное существо, формирующие гражданскую культуру общества. Следовательно, он будет мотивирован к замещению дефицитарных запросов и ценностей современными.

Смысловая нагрузка категории «качество жизни» охватывает также соответствие показателей содержания труда, условий и качества труда, а также возможности для проведения досуга, доступность качественных объектов культуры, оздо- ровления и лечения, состояние института семьи и брака, демографические показатели, социальную структуру города и села и т.д. Можно сказать, что использование категории «качество жизни» перемещает человека в центр современной социокультурной политики, которая в свою очередь изменяет содержание экономической политики, придает ей социокультурный характер за счет такого экономического развития, при котором создаются условия для роста социальных запросов индивида и возможностей их удовлетворения. И только такая экономическая политика может быть признана социально-ориентированной ${ }^{16}$.

Следующая категория социализирующей политики в современном российском обществе «стиль жизни». Она «отвечает» за распространение характерных черт современного образа жизни: определенные навыки трудовой деятельности, выбор соответствующего круга и форм общения, самореализации, особенности структуры потребления товаров и услуг, качество рекреации и проведения досуга, домашней обстановки, средств производства и т.д. Показатели, связанные с категорией «стиль жизни», определяют образ жизни людей, в частности, показывают, сумело ли общество перейти от традиционализма к современности, от аграрной экономики к индустриальной, как проходит модернизация и каковы ее результаты. Если большинство членов общества ведет современный образ жизни в соответствии с международными стандартами, то можно говорить о формировании общества «среднего класса».

Помимо вышеуказанных категорий, социализирующую роль традиционного общества современной России выполняют и показатели, соответствующие категории «стандарт жизни», которые определяют модель современного образа жизни и условий жизни и служат точкой отсчета для определения степени развитости или отсталости общества с учетом общепринятых и распространенных ценностей. Модель формируется на основе статистических показателей социальной жизни общества, различных групп и слоев общества, условий жизни и быта современной семьи, жизненного цикла, степени ур-

\footnotetext{
${ }^{16}$ Наука об экономике. Труды лауреатов Нобелевской премии. М., 2004. С. 157.
} 
банизации, развития техники, инфраструктуры, соотношения показателей экономического роста и роста производства товаров и производительности труда (так как именно такое соотношение показывает, с одной стороны, создало или нет государство условия для ведения социальной экономической политики, а с другой - насколько правомерны доходы населения, то есть заработаны доходы правовым или ухищренческим путем) и т.д.

Все эти категории создают общую картину «образа жизни», к которому люди должны стремиться в современных условиях. Иными словами, процесс их внедрения задействует адаптацию, привыкание - «подключает» индивидов к новым стандартам и принципам политической культуры. Категории «образ жизни» и другие перечисленные нами выступают в качестве механизма нормативной самоорганизации жизнедеятельности.

Третий этап социализации. Практическая реализация социокультурной политики - основа современной политической культуры

Третий этап социализации можно назвать также этапом распространения партисипаторной политической культуры и обеспечения партнерских отношений между обществом и государством. Иерархический тип политического управления и принцип «господство - подчинение» уступает место сетевой системе - системе сдержек и противовесов, которая носит правовой характер, так как в основе государственности лежат принципы международного права и конституционные обязательства государства перед обществом, базирующиеся на конституционализации человеческого фактора в государстве.

Третий этап социокультурной политики следует разделить на три основные блока.

1). Теоретическое объяснение необходимости конституционализации человеческого фактора и универсальных прав и свобод человека, основанное на Международном пакте о гражданских и политических правах, условиях формирования социального государства ${ }^{17}$, структуре прав человека и гражданина и т.д.

17 Права человека и социальное государство. Причины и условия формирования социального государства // Права человека. М. 1998. С. 197.
2) Формирование либерально-демократических основ институтов гражданского общества, усиление и четкое определение их роли, функций и задач как связующего звена между обществом и государством, а также утверждение и распространение базовых доктрин либеральных ценностей, устанавливающих ориентиры управления государством, основанном на принципе первичности человеческого фактора как основного капитала страны ${ }^{18}$.

3) Институционализация партнерских отношений общества и государства, благодаря которой все государственные институты начинают функционировать для улучшения «стандарта жизни», «качества жизни», «стиля жизни», «образа жизни» и т.д. Общество начинает выдвигать четко артикулированную иерархию своих социальных запросов, потребностей, которые являются важнейшими и первостепенными ценностями для индивидов. Степень удовлетворения таких запросов становится показателем эффективности или неэффективности властных структур.

Современная социокультурная политика России должна базироваться исключительно на принципе социально-ориентированной либерально-демократической политики и должна соответствовать п. 1 ст. 25 Всеобщей декларации прав человека, то есть учитывать первое и второе «поколения» прав человека, которые включают «человеческий потенциал», «качество жизни», «уровень жизни» и т.д., без которых основные права человека не приводятся в действие.

Главная цель принципа «выравнивания социального неравенства» современного российского общества заключается в том, чтобы обеспечить баланс роста богатства и благополучия граждан путем развития производства и расширения социальных функций государства. Этот принцип «государства благосостояния» (термин Дж. Роулса) направлен на обеспечение «качества жизни индивида» и тем самым принципа справедливого государства ${ }^{19}$.

Институционализация отношений между обществом и властью предполагает определение

\footnotetext{
${ }^{18}$ Там же. С. 214.

19 Всесторонний анализ концепции Дж. Роулса содержится у Г.В. Мальцева. См.: Мальцев Г.В. Буржуазный эгалитаризм. М., 2002. С. 184-214.
} 


\section{Политика и общество 11 (107) • 2013}

структуры таких отношений (выделение интересов сторон, артикуляцию целей и задач, нормативной матрицы отношений), что требует создания условий для расширения партисипаторной политической культуры в современной России. Общество и государство начинают приобретать опыт взаимодействия на новой институциональной основе. На смену пассивному приспособлению членов общества к обстоятельствам приходит контроль над динамикой процессов, что будет свидетельствовать об общем повышении уровня политической компетентности. При этом рациональность и ответственность станут основными критериями оценки эффективности государственной власти и институтов гражданского общества. Принципы договора и взаимной ответственности, соблюдаемые сторонами, будут способствовать выравниванию социального неравенства членов общества, что и станет показателем качества взаимодействия ${ }^{20}$.

В контексте социализирующей функции и роли политической культуры гражданское общество следует рассматривать как социокультурное поле, в рамках которого реализуются универсальные права и свободы человека как механизмы нормативной регуляции социальной жизни и социального контроля ${ }^{21}$, опосредующие взаимодействие социальной организации государства и институтов общества. Иными словами, это сфера социального взаимодействия, которая институционализируется системой социальных норм и осуществляет легитимацию государственной политики. При этом человек приобретает права «социального гражданства» ${ }^{22}$, а его политическая активность - статус социального движения. Это является первоочередной задачей социализирующей политики в России. На социализацию возлагается особая роль при формировании современной центральной зоны культуры, благодаря которой

\footnotetext{
20 Права человека и проблемы идентичности в России и современном мире. СПб., 2005. С. 20.

${ }^{21}$ См.: Резник Ю. М. Введение в социальную теорию. Социальная онтология. Пособие. М.: Институт востоковедения РАН, 1999.

22 Люблинский B.B. Трансформация общества и социальная политика в странах Запада: Вторая половина XX - начало XXI в. М. 2004. С. 213.
}

общество сформирует новые традиции, обычаи, паттерны поведения, приоритеты государственной политики, критерии ее легитимности и границы применения. Речь идет также об обучении индивидов навыку артикулировать свои социальные запросы и прибегать к протестным действиям вплоть до организации акций гражданского неповиновения, если государство не будет создавать условия для удовлетворения социальных запросов (такой опыт практически отсутствует в российском обществе).

Социализирующая функция политической культуры играет стратегически важную роль осуществления социокультурной политики это регулятивно-социализирующая деятельность органов государственной власти, направленная на изменение, поддержание и развитие общества в соответствии с современными общепринятыми стандартами «образа жизни», «качества жизни», «стиля жизни», «стандарта жизни», «уровня жизни»и т.д. путем придания им императивно-правового значения. Социокультурная политика включает систему нововведений, стандарты политической, правовой культуры, социальные изменения, внедрение социальных норм, социальной инициативы, социальной помощи, социального порядка и т.п., которые выступают как предпосылки качественных изменений. В заключение нельзя не отметить, что социализирующая функция политической культуры и социокультурная политика в целом недостаточно изучены российской наукой, а разработки в этой области до сих пор носили поверхностный и формальный характер, и предложенный в данной работе анализ лишь в некоторой степени восполняет указанный пробел.

\section{Библиография:}

1. Дюркгейм Э. Социология образования. М., 1996.

2. Тард Г. Законы подражания. СПб., 1989.

3. Giddings F.P. The theory of socialization. New York. 1892.

4. Parsonc T. The social system. Glencoe. 1951.

5. Смелзер Н. Социология. М., 1998. С. 95.

6. Кон И. Психология ранней юности. М., 1989.

7. Murray H. Explorations in personality. New York: Oxford University Press. 1938. 
8. Erikson E. Life history and the historical moment. New York. 1973.

9. Allport G.W. Pattern and growth in personality. New York. 1961.

10. Bandura A. Social learning theory. PrenticeHall. 1977.

11. Kelly D. Man's construction of his alternatives. New York. 1958. P. 58.

12. Орлова Э.А. Обыденная культура: организационные формы // Структура культуры и человек в современном обществе. М. 1987. С. 138.

13. Бергер П., Бергер Г., Коллинз Р. Личностноориентированная социология. М. 2004. С. 76.

14. Права человека и социальное государство. Причины и условия формирования социального государства // Права человека. М. 1998. C. 197.

15. Хьелл Л., Зиглер Д. Теории личности. 3-е изд. СПб.: Питер, 2006 13.Хьелл Л., Зиглер Д. Теории личности. 3-е изд. СПб.: Питер, 2006 Щупленков О.В., Щупленков Н.О. Политическая социализация и идентичность в условиях трансформации российского общества // NB: Проблемы общества и политики.-2013.№6.-C. 1-58. URL: http://www.e-notabene.ru/ $\mathrm{pr} /$ article_724.html

16. Деметрадзе М.Р.. Социокультурные исследования: теория и методология. Изд-во LAMBERT. Academic Publishing, 2011. 503

17. Деметрадзе М.Р.Центральная зона традиционных социокультурных ценностей как информационно-коммуникативный феномен. Nota Bene, 2012. $120 \mathrm{c}$.

18. Центральная зона современных социокультурных ценностей. Социализация как способ повышения человеческого фактора в обществах постсоветского пространства. Nota Bene, 2012. $120 \mathrm{c}$

\section{References (transliteration):}

1. Dyurkgeim E. Sotsiologiya obrazovaniya. M., 1996.

2. Tard G. Zakony podrazhaniya. SPb., 1989.

3. Giddings F.P. The theory of socialization. New York. 1892.

4. Parsonc T. The social system. Glencoe. 1951.

5. Smelzer N. Sotsiologiya. M., 1998. S. 95.

6. Kon I. Psikhologiya rannei yunosti. M., 1989.

7. Murray H. Explorations in personality. New York: Oxford University Press. 1938.

8. Erikson E. Life history and the historical moment. New York. 1973.

9. Allport G.W. Pattern and growth in personality. New York. 1961.

10. Bandura A. Social learning theory. Prentice-Hall. 1977.

11. Kelly D. Man's construction of his alternatives. New York. 1958. P. 58.

12. Orlova E.A. Obydennaya kul'tura: organizatsionnye formy // Struktura kul'tury i chelovek v sovremennom obshchestve. M. 1987. S. 138.

13. Berger P., Berger G., Kollinz R. Lichnostno-orientirovannaya sotsiologiya. M. 2004. S. 76.

14. Kh'ell L., Zigler D. Teorii lichnosti. 3-e izd. SPb.: Piter, 2006 13.Kh'ell L., Zigler D. Teorii lichnosti. 3-e izd. SPb.: Piter, 2006 Shchuplenkov O.V., Shchuplenkov N.O. Politicheskaya sotsializatsiya i identichnost' $\mathrm{v}$ usloviyakh transformatsii rossiiskogo obshchestva // NB: Problemy obshchestva i politiki.2013.-№6.-C. 1-58. URL: http://www.e-notabene.ru/ pr/article_724.html

15. Demetradze M.R.. Sotsiokul'turnye issledovaniya: teoriya i metodologiya. Izd-vo LAMBERT. Academic Publishing, 2011. 503

16. Demetradze M.R.Tsentral'naya zona traditsionnykh sotsiokul'turnykh tsennostei kak informatsionnokommunikativnyi fenomen. Nota Bene, 2012. 120 s. 